pathetically by the delegates present at Stockholm, who in a majority of cases agreed to avoid, so far as is practicable, the use of this band for television broadcasting. The second recommendation pointed out the danger of harmonies from certain broadcasting stations in Bands IV and V interfering with radio astronomy observations in the hydrogen band $1,400-1,427 \mathrm{Mc} / \mathrm{s}$. which, in the existing International Radio Regulations, is allocated exclusively for the radioastronomy service. It was recommended that administrations should take all practicable precautions to avoid such interference.

\title{
THE BRITISH ELECTRICAL AND ALLIED INDUSTRIES RESEARCH ASSOCIATION
}

$\mathrm{T}$ HE annual report of the British Electrical and Allied Industries Research Association opens with a reference to the fact that it records the work of the Association's fortieth year.

Of the work started by the Association in its early days which has contributed substantially to the development of the electrical industry may be mentioned, particularly, research on insulation, on circuit breaking and switchgear, and on the loading capacity of cables. These branches of work still feature largely in the Association's activities.

It was in the third year of the Association's existence that electricity supply undertakings, joining as associate members, initiated the co-operation in research between manufacturers and supply authorities which has continued ever since. Work which is of vital importance to the supply industry and which has been pursued continuously for many years is the determination of the properties of steam at high temperatures and of the characteristics of steel in relation to withstanding high temperatures and stresses.

The present major elassifications of the Association's research activities are as follows: insulation and dielectrics; switch and control gear; power plant; insulated cables; overhead lines; surge phenomena ; integrating meters ; magnetic materials ; transformers; flame-proofness and intrinsic safety; earthing; safety and circuit problems; rural electrification; heating, cooking and allied problems; electric equipment of automotive systems and communication interference. In addition, there is a small miscellaneous group designated "Unclassified Researches".

The more important results obtained during the year in these various fields, summarized in individual paragraphs of the report, comprise for the most part technological information which is applicable directly in the electrical industry, but there is in addition a substantial volume of new scientific knowledge.

An investigation of the resistance of industrial insulating materials to surface discharges, a phenomenon known as 'tracking', has shown that the resistance to tracking of a poor material is not increased greatly by a substantial increase in the creepage distance.

Measurements relating the temperature of buried cables to seasonal variations of soil properties have been made, and the possible advantages of using special 'backfills' for cable trenches are being investigated.

In relation to flame-proof equipment it has been shown that for some explosive gases obstructions in close proximity to, but outside, the flange gap increase the hazard of explosion, a wrapping of tape to improve dust tightness being particularly dangerous.
Following an investigation of the characteristics of electrical floor-heating for buildings, recommendations have been issued and are now being adopted.

It is also noted that interesting records were obtained last year of the behaviour of the heating system installed for frost protection under the road surface at the Mound in Edinburgh.

Work on vacuum circuit breakers, switches and contactors continues, and it is reported that the vacuum contactor has now reached the stage of commercial development.

In relation to interference arising from industrial radio-frequency equipment, it is stated that all the information has been obtained which is necessary for the preparation of statutory regulations.

In the field of agriculture, reference is made to investigations into methods of drying grain. It appears that for continuous-flow drying the most suitable electrical technique will be infra-red heating.

Among the fundamental researches conducted in university departments under the ægis of the British Electrical and Allied Industries Research Association may be mentioned the work carried on in Liverpool on the theory of conduction in semi-conductors. It is known that the conductivity of germanium increases by several orders of magnitude at fields of $2 \mathrm{~V} . / \mathrm{cm}$. and at liquid helium temperature. This phenomenon, which is often termed 'breakdown', has been shown to be quite unconnected either with instability or with destruction of the lattice. It can, in fact, be predicted theoretically on the basis of earlier work on 'hot' electrons.

Work on gas-discharge phenomena is also in progress with the Townsend ionization chamber on the measurement of ionization and attachment coefficients, and a comprehensive range of data has been obtained for carbon monoxide.

The velocity distribution of cathode particles originating from the spot of a low-current arc between copper electrodes in vacuo has been investigated at Oxford.

At the University of Durham experiments are in progress on collision ionization at ultra-high frequencies.

Perhaps the most noteworthy illustration of the traditional freedom of scientific inquiry occurs under the heading "Astrophysics" in the section of unclassified research work.

Originating in the important technological investigation of are phenomena in eircuit breaking, there has developed the idea of applying fundamental electrical discharge theory to problems on the macroscopic scale of astrophysics. Since 1944 several papers dealing with the development of these hypotheses have been published. 
During the past year, observations have become available from astrophysical and space research which confirm predictions of this general theory in some detail.

The application of electrical discharge theory to explain a well-known type of stellar spectrum suggested the existence of spiral nebulæ on a stellar scale. Photographic evidence of the existence of such nebulæ has become available. The theory explains the general form of the planetary nebulæ and of the gas movements observed in them.

Evidence in support of another prediction has resulted from satellite observations by U.S. naval scientists. The observations of $80,000-\mathrm{V}$. X-rays associated with solar flares implies the existence of temperatures of about $100,000,000^{\circ} \mathrm{K}$. in solar atmospheric electrical discharges. The prediction that such temperatures must exist in this region was made from electrical discharge theory applied to magnetic storms.

Another interesting by-product of theoretical work in a different field is a new method of measuring the surface tension of a clean surface in a liquid. This results from the mathematical solution of the problem of the equilibrium shapes of bubbles in electrical and centrifugal fields which was required in a study of the electrical breakdown of liquids, itself part of an investigation on breakdown of highly stressed im. pregnated dielectrics.
The most notable addition, during the year, to the Association's experimental resources has been the building and equipping of a Creep Testing Laboratory, intended to accelerate the important investigations on the creep behaviour of steels for use at temperatures above $1,050^{\circ} \mathrm{F}$. $\left(565^{\circ} \mathrm{C}\right.$. $)$.

At the end of the year under review a major reorganization of the Association's committee structure was put into effect. Six divisional committees now guide and superintend the Association's work, replacing twenty-two sectional committees and eighty-one research committees.

An interesting reference is made to the desirability of fostering still clozer relations between the Association and the universities and technical colleges. Through its extra-mural programmes the Association already maintains close contact with quite a number of departments in universities and technical colleges. To supplement this, special facilities were instituted to provide for all universities and technical colleges in the Commonwealth obtaining ${ }^{+}$he published reports of the Association. A further step has now been taken in the development of this policy in that professors of electrical engineering and heads of electrical engineering departments in technical colleges have been invited to apply for associateship of the British Electrical and Allied Industries Research Association with full membership benefits.

J. Greig

\section{FOUR DECADES OF STATE FORESTRY IN NEW ZEALAND}

$\mathrm{T}$ HE annual report of the Director of Forestry in New Zealand for the year ended March 31, 1960, made to Sir Ernera Tirikatene, the Minister of Forests, is full of interest*. Essentially it consists of 37 appendixes in tabular form, from which progress towards various objectives can be measured, if desired. This will be the last report made by $\mathrm{Mr}$. Entrican, who has just retired after long service.

The report is refreshing for its frankness on some of the mistakes made in the past. It does not disguise the difficulties encountered in the somewhat erratic progress being made towards the building up of a sound forestry practice and the creation of areas of managed forest which are expected to make important contributions to the national economy.

The State service is organized into a number of divisions which deal with management, public and private forestry, development, which comprises training and research, protection forestry, engineering work, operations, industrial operations and, finally, commercial operations.

In the past no more than lip service has been paid to the fundamental principle in forestry of sustaining the yield, and in this report we have a plain confession of neglect to adhere to that principle. "Thus", it says, "on a 2,000-acre area to be managed on a 40-year rotation, 50 acres would be planted annually, with the first $\mathbf{5 0}$ acres coming to maturity ... in the forty-first year, concurrently with the completion of planting over the whole area." New Zealand speaks thus from bitter experience. The Murupara working circle in the largest planted forest there-Kaingaroa-covers 200,000 acres, the oldest portion of which is 37-47 years of age and

* New Zealand. Report of the Director of Forestry for the year ended 31 March, 1960. Pp. 115. (Wellington: Government Printer, extends to 10,000 acres only. The next age-class -27-37 years old-covers no less than 150,000 acres, the remaining 40,000 acres being of younger ages. This vast mass of 150,000 acres, composed mainly of Monterey pine (Pinus radiata D. Don) is described as "steadily moving towards maturity en masse". For various reasons it has been found impossible to cope with the tending of this large area and, in respect of other species in which there are fewer natural deaths, the growing-stock is said to be "accumulating towards stagnation". Here there is a lesson for other countries engaging in large-scale afforestation on fertile land.

New Zealand is anxiously trying to find an outlet for what is frankly called its second-grade timber as a pulp-wood, having produced an excess of certain assortments. An export trade to Australia has been established, but New Zealand openly looks ahead to supplying pulp and paper wood to the rapidly developing populations of the Asiatic countries. A strong plea is made for increasing the area of plantations of exotic conifers, even on good farming land, to produce timber for export, and it is the producer of not enough butter-fat per acre-not of mutton and wool-that is being urged to switch over to forestry. Farmers are asked to plant trees extensively, even to the extent of providing one out of the three million acres of the prescribed afforestation programme. which is expected to increase the area of planted exotic trees to $3,000,000$ acres by the year 2025 .

Unlike Great Britain, New Zealand still has a large area of indigenous forest. In 1840 the area there covered by these must have amounted to about two-thirds of that of the whole country. Since then they have been considerably reduced. Their treat. ment has followed the usual Anglo-Saxon pattern of 